\title{
How Gender, Age and Education Influence the Entrepreneur's Social Orientation: The Moderating Effect of Economic Development
}

\author{
Longinos Marín ${ }^{1} \mathbb{D}$, Catalina Nicolás ${ }^{2, *(\mathbb{D})}$ and Alicia Rubio ${ }^{2}$ \\ 1 Marketing Department, University of Murcia, 30100 Murcia, Spain \\ 2 Department of Management and Finance, University of Murcia, 30100 Murcia, Spain \\ * Correspondence: catalina.nicolas@um.es
}

Received: 8 July 2019; Accepted: 17 August 2019; Published: 21 August 2019

check for updates

\begin{abstract}
A social entrepreneur is an individual that creates a company to generate social value. Social entrepreneurs tend to develop these initiatives because they have a strong social orientation. The reason why people have a stronger or weaker social orientation has been analyzed through the lens of different subjects, among biological, social, and behavioral sciences. However, the literature does not agree about which variables influence individuals to have more or less social orientation. We investigated which variables influence the entrepreneur's social orientation by using a large sample of individuals $(n=176,460)$ in 59 countries. Our results show that an entrepreneur's social orientation is stronger for women, more educated, and older people. The economic development of the country moderates these relationships among the social orientation, gender, and education level of the individual. We found that the individual's social orientation increases at the same rate as the country's development level.
\end{abstract}

Keywords: social entrepreneur; social orientation; individual variables and economic development

\section{Introduction}

There is an increasing number of individuals who have decided to create social enterprises. The social entrepreneurial activity rate worldwide went from $2 \%$ in 2009 to $3.7 \%$ in 2015 [1], which means that the role of social entrepreneurs is becoming more determinant in a country's growth and in the fight against social, economic, and environmental challenges. This type of entrepreneur knows that governments and institutions cannot satisfy unlimited social needs, so they initiate activities that solve social problems [2-4]. They focus their efforts on responding to the difficulties concerning the endurance faced by neglected populations, an equitable allocation of scarce resources, the development of activities that are sustainable and respect the environment, or the adaptation of technology to local needs and infrastructure, among other problems [5-7]. Therefore, it is possible to find social enterprises such as Terracycle (Trenton, NJ, USA), for example, whose aim is to eliminate waste around the world by recycling what is usually considered nonrecyclable, or such as APOPO, which detects anti-personnel mines with its HeroRats, for their later deactivation.

Analyzing the significance of creating economic or social value for the entrepreneur enables the classification of entrepreneurs on a continuum that ranges from those whose only priority is to earn money (economic entrepreneurs), to those whose only objective is to create social value (social entrepreneurs) [8]. This continuum depends on the individual entrepreneur's social orientation [9]. Among social entrepreneurs, there are different orientations or ways of creating social value. One type of entrepreneur creates their business with only a social purpose in mind, while another seeks hybrid models, combining social and economic objectives. This makes it possible 
to talk about pure social enterprises or hybrid social enterprises [10]. Therefore, we can have a more or less entrepreneurial social orientation, and can decide the intensity with which entrepreneurs prioritize social over economic objectives. However, it is important to remember that the economic objectives of social entrepreneurs are regarded as subordinate and a necessary condition rather than a dominant aim [8].

The literature on social entrepreneurship has grown considerably since the 1990s. Many studies have focused on definitions and typologies [11], analyzing which factors influence the creation of this type of enterprise [12,13], and examining any differences found between social and economic entrepreneurship [14]. However, the factors that influence an entrepreneur's social orientation and their orientation dependencies are two areas that have rarely been analyzed $[15,16]$.

Most previous studies have taken in account the influence of the variables of gender, age, and education on social entrepreneurship. When studying gender, previous research has shown that since stereotypes and cultural values that describe suitable behaviors for each gender are more social-field-oriented than male-oriented, they are the ones who should undertake socially to a bigger extent [17]. In terms of age, the difference in cultures and life expectancy between countries can cause differences in social entrepreneurial rates. Finally, analysis of the level of education shows that university education positively influences the propensity to become a social entrepreneur in all economies [18].

Although the literature has analyzed the influence of gender [19], age [20], and education level [21] on social entrepreneurial intentions individually (as antecedents and as control variables), almost no research has explored these variables simultaneously in a framework. We also analyzed the moderating effect of a country's development level on each of the variables under study. In this study, we sought to understand how these variables influence the generation of social value, a phenomenon that has not been studied in the literature to date.

Therefore, the contribution of this study to academic literature is two-fold: To help define the profile of the social entrepreneur by simultaneously testing the influence of three relevant variables (age, gender, and education) with a strong data set (7.891 social entrepreneurs), and to contribute to defining the profile of a social entrepreneur according to the country in which they operate, since the profile will be different depending on the level of economic development (Figure 1).

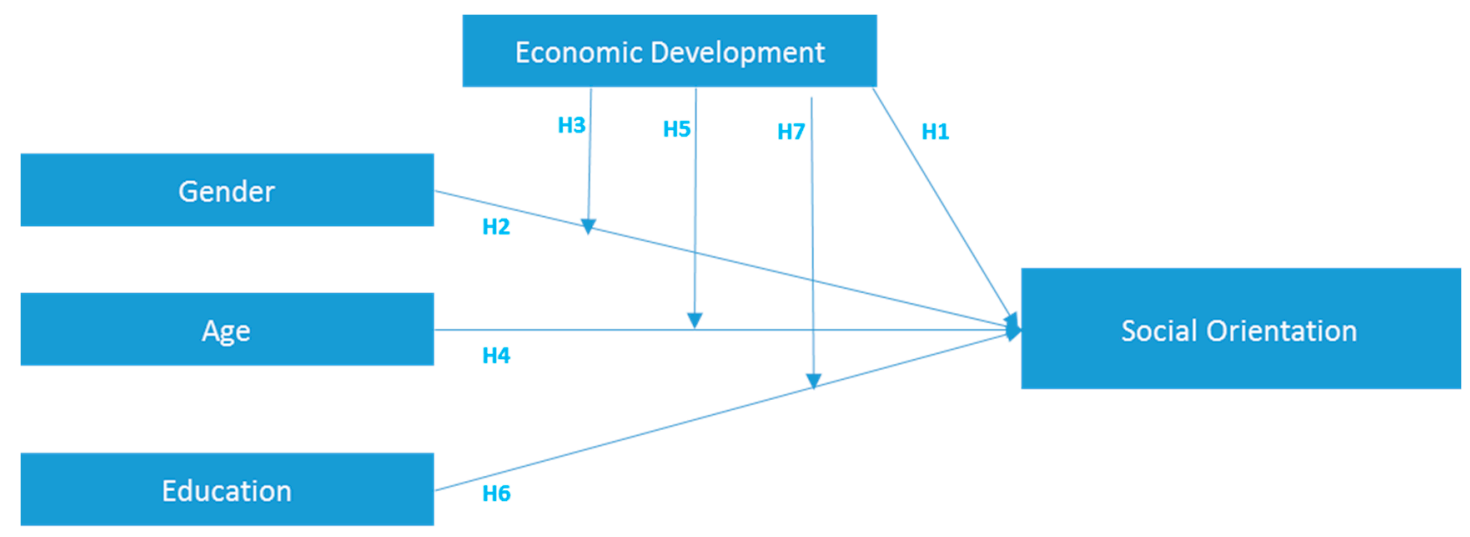

Figure 1. Determining factors for creating social value by the social entrepreneur.

Additionally, we addressed the gap in the literature on how entrepreneurs link and categorize the series of values they aim to create with their enterprises [22], so new hypotheses were developed to demonstrate how individual variables could have several impacts on social orientation. In spite of the increase in social entrepreneurship research, previous investigations have still recently been characterized by mostly theory and case studies, but very little comparative cross-country empirical research [23]. 
Furthermore, this could help politicians and entrepreneurship drivers to understand the characteristics of these entrepreneurs better, and determine whether the level of development of the country could significantly aid in implementing efficient policies to promote social entrepreneurship tailored to the characteristics of each territory. These practices would require the creation of more social enterprises and, in turn, lead to greater social benefits for society in general.

Our analysis exploited the Global Enterprise Monitor (GEM) database, which included developed, developing, and undeveloped countries, with the most recent data being form 2015. The GEM survey was given to at least 2000 individuals annually in 59 countries. The data at the individual level (176,460 usable observations) were created using surveys that enabled the production of stratified samples taken from the data, which were related to the entire working age population of each country studied.

To achieve those objectives, the study was organized in the following way. Firstly, we analyzed the current literature on the individual's social orientation and the influence that the variables under study have on the individual's social orientation. We analyzed the literature on how these variables moderate a county's development level. The hypotheses used in this research were taken from this review. They were contrasted with a sample of 7891 social entrepreneurs of 59 countries, which were classified depending on their development level. Finally, the results are discussed and their research implications are analyzed.

\section{Literature Background and Development of Hypotheses}

Any business project which is developed with a social objective- to reduce or mitigate a social problem or market failure and to create social value-and which operates with the same financial regulation, innovation, and determination of a private sector business [2] is defined as a social entrepreneurship. Therefore, social entrepreneurs can be defined as change agents that employ entrepreneurial means to find systemic solutions to social and environmental problems [24]. They must have a clear and specific social goal that prioritizes social value creation [8], although the initiative of social entrepreneurship can come both from the business sector (business approach motivated by a mission) and nonprofit organizations (earned income school of thought) [25]. Thus, this type of entrepreneurship can comprise a rather broad range of organizations, such as (1) traditional nonprofit organizations, which have a clear social mission and which are not dependent on market income (the commercial activities undertaken in this type of business can produce profits that will enable the business to maintain its operations), (2) for-profit organizations that have a clear mission to seek both social and economic objectives, and (3) hybrid organizations whose motives are both not-for-profit and for-profit. This latter type of business requires the creation of economic value and profit as a necessary condition for ensuring financial viability [10].

Entrepreneurship is determined by a different set of variables: The personal characteristics of an individual, including socio-demographics and personality traits, the economic environment and institutions, and sociological variables $[8,13]$. Social entrepreneurship research, which has been mostly theoretical [8] or qualitative thus far [26], tends to follow these research streams. Specifically, it concentrates on understanding social enterprise boundaries and the attributes of individual social entrepreneurs, focusing on their intentions, goals, identity, and values, or the missions of their associated organizations [27,28]. Previous studies have connected social business to initiatives by single people, though others have argued that these activities may be undertaken by groups of individuals [29]. Likewise, social entrepreneurship is embedded in the context in which it takes place [26]. For this reason, some papers compare activities across different industries, other authors explore factors assumed to contribute to social impacts within a single sector [27], while others focus on national economies [8], cross-national comparisons [1] or different types of economic developments [18]. Others conceptualize social enterprise in different subjects, such as in biology or the social and behavioral sciences [30]. This research is still on the rise today; its aim is to demonstrate which variables determine an individual's social orientation. 
Very little is currently known about the relationship between an individual's social orientation and the economic context. To explore this in our research, we focused on analysis of the social entrepreneur's profile considering different levels of economic development. Specifically, we found that gender, age, and education background characteristics of social entrepreneurs differed depending of the stage of economic development of the country in which they resided and practiced business.

The proposed model addressed individual sociodemographic variables at the micro level. Although the level of economic development is a macro variable, it may also capture some individual variables (micro), such as individual welfare, individual income, and services availability. In addition, we used the economic development variable to define the social entrepreneur profile of each particular country. We introduced economic development as a moderator variable, to the extent that it enhances or attenuates the effects of the independent variables (gender, age, and education) on entrepreneur social orientation. All of this allowed us to suggest that entrepreneurial social orientation is primarily determined by gender, age, and education. In addition to a direct effect, these relationships are moderated by the country's economic development (Figure 1).

\subsection{Economic Development and Social Orientation of Entrepreneurs}

Although social entrepreneurship is an unusual phenomenon in general, it has become a significant economic phenomenon at the global level, leading to the development of new innovative business models to satisfy basic human needs and becoming almost as important as commercial entrepreneurship in developed countries [2]. Cross-national comparisons of social entrepreneurship rates highlight that there are differences in the number of social entrepreneurs across countries. In 2015, the GEM showed that the average social entrepreneurship rate was 3.7\%, but this rate varies between $0.3 \%$ in Iran and 14\% in Senegal [1]. This variation across countries may be based on a society's culture, economic development and other institutional variables, such as beneficial regulation, education, and training opportunities, as well as the fact that there are cultures that bring about pro-social or innovator behavior [23,31,32]. In addition, as shown in the 2017 Global Entrepreneurship Monitor Report, undeveloped countries showed the lowest average opportunity motivation; one-third of entrepreneurs in these countries started out of necessity, and this may reflect that the individual's initiatives are motivated by needs that originate from the local community. Moreover, while theory shows that higher necessity levels may give rise to a higher commitment to social entrepreneurship, this is not proven in the data. The only fact that can be assessed is that people who live in countries with higher economic and social development levels are in a more favorable position to create social enterprises [23,33].

Regarding the entrepreneur's social orientation, there is a higher prevalence of for-profit social enterprises in less developed countries, and there is a significant minority of traditional non-profit organizations, especially in developing countries, who seem to want a profitable business that also addresses social issues [1]. Even though the social distress levels are higher, people are more concerned about survival, and are, therefore, in a situation where payoffs encourage hybrid entrepreneurship [11]. These authors base their work on the reality that the welfare state is weak or even nonexistent in less developed countries, and, in addition, the economic situation of these territories is often complicated, so families usually do not have enough money to live. Therefore, it is understood that social entrepreneurs in these territories will create companies not only to generate social value, but, due to the serious needs they have, they must also set the objective of generating their own income with which they can support themselves and their families economically. These findings are supported in the study by Bosma et al. [1]. As stated in the referenced research, when the levels of economic development are lower, new entrepreneurial activities with social objectives are more closely related with those of ordinary new businesses. Based on this, we affirm that:

Hypothesis 1 (H1). The country's economic development has a positive effect on the entrepreneur's social orientation. 


\subsection{Gender}

The probability of men being involved in a social entrepreneurial activity is higher, and this difference increases as the country's development level increases [34]. However, the difference in social entrepreneurship predominance is not as high as in traditional commercial entrepreneurship [1]. These results may suggest that men care more about achieving and obtaining economic benefits, while women may care more about social value goals. For example, Hechavarría [22] reported that women's average social goal is $33 \%$ compared to $26 \%$ for men in countries such as Japan, the Netherlands, Norway and the USA. In addition, these results align with environmental behavior research, such as that of Hunter, Hatch, and Johnson [35], which suggests that gender differences in environmental concerns reveal that the likelihood of women being concerned about environmental issues (recycling, buying organic produce or driving less) is higher than for men due to an extension of their ethics for caring and their corresponding desire to protect nature.

This difference between men and women is explained by the gender role theory [36], which states that it is the culture and not the biological predisposition that defines socially acceptable behavior for each gender. While we relate the male role with control or achievement, making men responsible for financial family support, women have traditionally been associated with working at home, doing housework and looking after children and other dependent people. These roles and stereotypes lead to the conclusion that it is men who are ideal to start and run a business [17]. Meanwhile, this argument is also supported by reference [37], which puts forward a hegemonic masculinity theory, by stating that in the business world there is a hierarchical order between men and women, where men are considered the norm and women the exception to the rule.

Nevertheless, the fact that women have these preconceived roles and are conditioned by hegemonic masculinity principles can lead to differences in the way in which they run their businesses, since their decisions are guided by different objectives to those of men [19]. In fact, there are studies that show that women decide to become entrepreneurs mainly due to social rather than economic (men's main motivation) objectives [17].

This fact could explain why women do not only perform many social actions but are also the main protagonists in social entrepreneurship [38]. The objectives of social enterprises are directly related to altruism, care and protection of others, while the aim of commercial enterprises is to produce an economic benefit for their entrepreneurs. Therefore, women prefer to start a social enterprise as it is more suitable for their roles and emotional goals rather than starting a commercial enterprise [14].

In addition, while the main objective of a commercial enterprise is to generate economic benefit, social enterprises have a different goal, which clearly focuses on developing sustainable solutions that create social value through economic activity [14]. Social enterprises align more with the female role due to social objectives, as women focus more on activities related to helping. They are more likely than men to get involved in volunteer activities, and have higher participation in the tertiary sector than men, even in countries such as the United States [17].

Accordingly, we assess that the economic environment where social entrepreneurship takes place determines the impact of gender on social orientation. This argument leads us to affirm that:

Hypothesis 2 (H2). Social orientation is greater form women than for men.

\section{Moderator Effect of Economic Development}

Although there in an increase in the number of social enterprises, and female enterprises [39] are being promoted more strongly, the data in this sense show that there is a significant difference in the importance of women in social entrepreneurship when comparing countries and even, economic groups [1].

When analyzing samples from different countries, grouped by development level, it can be concluded that when the development level decreases, so does the gender gap [14]. 
This fact is motivated by two factors. First, the weak economic systems of these countries, with high unemployment rates, high job insecurity and low wages, result in women trying to escape poverty by becoming self-employed due to necessity [14]. Second, note that low efficiency levels reduce entry barriers, which encourages starting new enterprises, making it possible for women to establish companies in less developed countries [40]. This result is evident in the data; less developed economies have the highest average female entrepreneurship activity rate, as well as the highest rate compared to men. Moreover, in undeveloped countries the likelihood of men and women to start a business out of need is almost the same [18].

Therefore, as the economic development level increases, women can create and develop social ventures, pursuing their entrepreneurial objectives in more moral, social settings. On the other hand, women dealing with necessity may create social value, but they may balance economic goals in order to support their families and themselves economically. With these arguments we can state that:

Hypothesis $3 \mathbf{~ ( H 3 ) . ~ T h e ~ e c o n o m i c ~ d e v e l o p m e n t ~ o f ~ t h e ~ c o u n t r y ~ m o d e r a t e s ~ t h e ~ i n f l u e n c e ~ o f ~ g e n d e r ~ o n ~ t h e ~}$ entrepreneur's social orientation.

Hypothesis 3.1 (H3.1). In developed countries, social orientation is greater for women than for men.

Hypothesis 3.2 (H3.2). In undeveloped countries, social orientation is greater for men than for women.

\subsection{Age}

When analyzing the relationship between age and social orientation of the social entrepreneur, the literature states that it is older individuals who start a business in order to generate greater social value [18]. The authors specifically base their argument on the fact that time is a key factor in regard to detecting social problems. People detect a large number of social problems that need aid from the public, and they observe that time passes and the problems are not addressed by public administrations [18]. Therefore, it is older individuals who identify more social problems in their environment, having been able to observe and analyze them over the years.

However, age does not only condition the individual in regard to detecting social problems. The truth is that, in addition, entrepreneurs must feel capable, a term denominated in the literature as perceived self-efficacy [38]. There is research that specifically concludes that age also has a direct relationship with the individual feeling more qualified to undertake such a task [41]. This is justified by the idea that an older person has had more time to become familiar with both the business world and the social problem. For the social entrepreneur, knowing how to manage a business and knowing the social problem is essential to solve the social problem, something that usually happens over the years.

Moreover, being older is directly related to the individual having more work experience, something that has already been analyzed by several authors who understand that it is beneficial for entrepreneurs [41]. Social entrepreneurs start up companies related to their own life experiences, learning from what works and what does not, seeking practical solutions to the limitation of resources and adapting to a series of changes [42]. Johnson [43] reaches this same conclusion, which shows that, to a greater extent, older people with long work experience are the one who set up companies in order to achieve social improvements.

In addition, it is also possible to find more arguments in the literature that show that age is a determining factor in the individual's social orientation. In particular, this argument has its basis in Maslow's theory of motivation [44]. This theory classifies individuals' needs into four categories which are assigned a hierarchical level on the well-known pyramid of needs. Maslow considers that an individual must have his lower needs satisfied in order to reach the higher ones. For this entrepreneur, it is understood that individuals can satisfy their economic needs over time, having been able to obtain higher-level jobs, better remuneration and having been able to spend years saving. Therefore, as people 
get older, they will be able to dedicate time to personal satisfaction by creating social value for others since their other needs are satisfied. All these arguments lead us to propose that:

Hypothesis 4 (H4). Age has a positive effect on entrepreneur's social orientation.

\section{Moderator Effect of Economic Development}

Recognizing that adulthood is not the same in developed countries as in undeveloped countries [18], we considered the idea that the level of development will influence the age of social entrepreneurs with greater social orientation. In undeveloped countries, the average number of children families have is higher than in developed countries. This leads to families in these countries having greater economic needs. Specifically, this is because, on the one hand, the economic situation of families in these countries is more complicated than in developed countries. On the other hand, family units are composed of a greater number of individuals in less developed countries; that is, couples in these territories have children throughout their entire fertile life. For example, in 2016, the fertility rate of families in Niger was 7.239, while this figure dropped to 1.33 for families in Spain (World Bank Group 2018). In less developed countries, young people are the ones who have fewer family responsibilities and, therefore, those who have fewer economic needs, as opposed to the older population.

Therefore, it is believed that adults in undeveloped countries will be more economically oriented as they have dependent children up to a high age, so they have more economic needs to support their family than younger individuals who have a smaller number of children. Hence, they create social enterprises with which they not only help others, but with which the social entrepreneur also obtains an economic income to support his large family unit. In contrast, family units are smaller in more developed countries in addition to having greater resources, which indicates that there are fewer economic difficulties in these territories. Therefore, in developed countries, older individuals are the ones who have perceived the greatest number of social problems, and who have greater work experience, who have satisfied most needs, who do not have family responsibilities, and who can therefore afford to be more socially oriented.

Those least likely to become social entrepreneurs in the poorest countries are young people (18 to 24); however, young people are the most likely to start social enterprises in the richest countries [23]. As a result, we hypothesize that:

Hypothesis 5 (H5). The economic development of the country moderates the influence of age on entrepreneur's social orientation.

Hypothesis 5.1 (H5.1). In developed countries, social orientation is greater for young than for old entrepreneurs.

Hypothesis 5.2 (H5.2). In undeveloped countries, social orientation is greater for old than for young entrepreneurs.

\subsection{Education}

There are studies that show that there is positive relationship between the level of education and social entrepreneurship [18]. This positive relationship is due, in the first place, to the fact that the most qualified entrepreneurs increase their ability to work in complex environments [45]. Undoubtedly, the adoption of social orientation complicates the management of the company. Social entrepreneurs often work with clear social objectives in highly complex and uncertain environments [46].

In general, social enterprises are usually related to a greater number of difficulties, not only because they tend to be found in markets that do not operate very well, since that is where the social problems they wish to solve are found, but because, they also have scarce economic resources, so they cannot afford to hire the most talented workers [14]. Benefits are not reinvested in the best business operation, but in solving the social problem that gave rise to the company [46]. Thus, it is stated that 
the adoption of a greater social orientation by the individual implies a greater social commitment since obtaining social value involves a greater amount of similar risk than if the only aim is to generate one's own economic benefit.

Taking into account these arguments, there are authors who argue that a higher level of education also increases the individual's social commitment [11]. This is because having acquired more knowledge and greater skills, as is the case with a higher level of education, makes the individual more socially oriented [42] and can make the individual perceive social problems as business opportunities to a greater extent. It can be said that a higher education level increases the individual's social commitment, and therefore the probability of being more socially oriented [11].

Those individuals with a higher education level are more likely to start social ventures [23]. Accordingly, it is assessed that:

Hypothesis 6 (H6). Education has a positive effect on an entrepreneur's social orientation.

\section{Moderator Effect of Economic Development}

Research indicates that a country's development level decreases at the same rate as the entrepreneur's training level if the education level variable is considered [11]. The authors base their argument on the fact that, in undeveloped countries, the training level of the population, in general, is lower than in the rest of countries. For this reason, entrepreneurs from these countries also have a lower training level. In undeveloped countries, not all of the population can have access to education in the same way, due to the socioeconomic conditions being worse in these types of countries [47].

Moreover, the "brain drain" that usually takes place in less developed countries must be considered. That is, the most qualified people in these territories decide to move to countries with higher levels of development in hopes of finding a better professional future. All this leads to a population with a lower training level compared to the one of the developed countries where the most qualified people decide to go [47].

Based on the idea that there are less qualified people in less developed countries, it is thought that development will determine the relationship between the individual's social orientation and his education level [11]. As shown in the previous paragraph, in less developed countries, where economic needs are high, better qualified individuals will take advantage of their training to obtain better wages and/or income to support their families or even improve their standard of living [47]. Therefore, the most qualified people in these countries will have a greater economic orientation than the highly qualified in the most developed countries. This is because, in addition to creating social value, they create economic value with which to improve their own well-being and that of their family members.

In contrast, in developed countries, individuals in general do not have as urgent a need for survival as those in less developed countries. Therefore, and bearing in mind that an individual's education involves higher levels of social orientation and that it is also essential for the efficient management of social enterprises (which support higher risk levels and a greater number of difficulties than economic enterprises) [18], it is believed that the most qualified individuals in these types of countries will be more socially oriented than the most qualified individuals in undeveloped countries. Consequently, we hypothesize that

Hypothesis 7 (H7). The country's economic development level moderates the influence of education on entrepreneur's social orientation.

Hypothesis 7.1 (H7.1). In developed countries, social orientation is greater as entrepreneur is more educated.

Hypothesis 7.2 (H7.2). In undeveloped countries, social orientation is greater as entrepreneur is less educated. 


\section{Methodology}

The data is taken from the GEM project. The GEM project calculates the predominance rates of businesses in different countries by using population samples. The data for this paper were collected during the summer of 2015. A standardized survey was administered to a representative sample of adults (aged between 18 and 64) in each country, with a total sample of 176,460 individuals for all the countries (Table 1). The raw data were given the appropriate weights so as to match each country sample with the age and gender structure of the U.S. Census International Data Base in order to reach general population conclusions.

In order to identify those individuals who are in the process of establishing a business, the respondents were asked: "Are you currently by yourself or with other individuals trying to start a new business, including any self-employment or selling any goods or services to others?" Those who replied "yes" were asked two extra questions. These questions were used to differentiate those individuals who were truly committed to a new business from those were thinking about it, but still not committed to it. To identify those individuals in the process of creating a social business, they were also asked if they were currently by themselves or with other individuals in the process of starting or running a business whose objective is socially, environmentally or community based. Those individuals who replied "yes" were classified as social entrepreneurs and those who replied "no" as nonsocial entrepreneurs. A total of 7891 social entrepreneurs were found in the sample.

More information about the GEM study and its methodology is provided in Lepoutre et al. [11].

Table 1. Sample distribution.

\begin{tabular}{|c|c|c|c|}
\hline Economic Development & Countries & $\begin{array}{c}\text { Total } \\
\text { Sample }^{1}\end{array}$ & $\begin{array}{c}\text { Social } \\
\text { Entrepreneurs }\end{array}$ \\
\hline $\begin{array}{l}\text { Stage 1: Factor-driven (includes } \\
\text { transition countries to stage 2) }\end{array}$ & $\begin{array}{l}\text { Botswana, Burkina Faso, Cameroon, Egypt, India, Iran, } \\
\text { Philippines, Senegal, Tunisia, and Vietnam. }\end{array}$ & 21,964 & 1563 \\
\hline $\begin{array}{l}\text { Stage 2: Efficiency-driven } \\
\text { (includes transition countries to } \\
\text { stage 3) }\end{array}$ & $\begin{array}{l}\text { Argentina, Barbados, Brazil, Bulgaria, Chile, China, Colombia, } \\
\text { Croatia, Ecuador, Estonia, Guatemala, Hungary, Indonesia, } \\
\text { Kazakhstan, Latvia, Lebanon, Malaysia, Macedonia, Mexico, } \\
\text { Morocco, Panama, Peru, Poland, Puerto Rico, Romania, South } \\
\text { Africa, Thailand, and Uruguay. }\end{array}$ & 72,333 & 3067 \\
\hline Stage 3: Innovation-driven & $\begin{array}{l}\text { Australia, Belgium, Finland, Germany, Greece, Ireland, Israel, } \\
\text { Italy, Luxembourg, Netherlands, Norway, Portugal, Slovakia, } \\
\text { Slovenia, South Korea, Spain, Sweden, Switzerland, Taiwan, } \\
\text { United Kingdom, and United States. }\end{array}$ & 82,163 & 3261 \\
\hline
\end{tabular}

\subsection{Measures}

1 dependent variable, three independent variables and one moderator were used to test the hypotheses.

To identify the entrepreneur's social orientation, individuals were asked if it was more important for them to generate value for society and the environment than to generate financial value for their company. They responded with one of the five-category variables. The five categories were $1=$ 'Completely Disagree,' 2 = 'Partially Disagree,' 3 = 'Neither Agree nor Disagree,' 4 = 'Partially Agree' and $5=$ 'Completely Agree'.

Gender: The respondents ticked if they were male or female, which made it possible to create a dummy variable with value 1 for men and value 0 for men.

Age: The respondents provided their year of birth, so a continuous variable was used to measure age (aged between 18 and 64) age.

Education: The respondents were asked about the highest level of education they had achieved. They responded with one of the seven-category variables in all the countries. The seven categories were "Pre-primary education," "Primary Education or first stage of basic education," "Lower secondary or second stage of basic education," "(Upper) Secondary education," "Post-secondary non-tertiary education," "First stage of tertiary education," and "Second stage of tertiary education." Regarding the 
moderator variable and following Bosma et al. [1], the countries were classified into three categories: (1) factor-driven (it includes transition countries to stage 2); (2) efficiency-driven (it includes transition countries to stage 3); (3) innovation-driven. This economy classification by economic development level is adapted from the World Economic Forum (WEF). According to this classification, in the factor-driven stage, subsistence agriculture and extraction businesses are predominant, relying heavily on (unskilled) labor and natural resources. In the efficiency-driven stage, the economy has become more competitive having production processes that are more efficient and increased product quality. As development progresses into the innovation-driven stage, businesses are more intensive in knowledge and the service sector expands (http://weforum.org). Economies in transition from factor-to efficiency-driven have been grouped with factor-driven economies, while those in transition from efficiency-to innovation-driven have been included in the efficiency-driven category.

Data Analysis and Results

An initial analysis of the relationships between the variables under study was performed. The Pearson correlation for all the study variables for the final sample of 7891 observations is shown in Table 2. The correlation matrix shows that almost all the variables have positive and statistically significant bivariate correlation with social orientation. The only negative relationship for social orientation is with undeveloped countries.

Table 2. Correlation matrix and variable details.

\begin{tabular}{|c|c|c|c|c|c|}
\hline Variable & 1 & 2 & 3 & 4 & 5 \\
\hline 1 Gender $^{1}$ & 1 & & & & \\
\hline 2 Age $^{2}$ & 0.003 & 1 & & & \\
\hline 3 Education Level ${ }^{3}$ & $0.025^{* *}$ & $0.064^{* * *}$ & 1 & & \\
\hline 4 Undeveloped Countries ${ }^{1}$ & $-0.021^{* *}$ & $-0.131^{* * *}$ & $-0.388^{* * *}$ & 1 & \\
\hline 5 Developing Countries ${ }^{1}$ & 0.001 & $-0.035^{* * *}$ & $0.043^{* * *}$ & -0.394 & 1 \\
\hline 6 Social Orientation 4 & $0.037^{* * *}$ & $0.059^{* * *}$ & $0.158^{* * *}$ & $-0.143^{* * *}$ & $0.077^{* * *}$ \\
\hline
\end{tabular}

${ }^{1}$ Dummy Variable. ${ }^{2}$ Aged 18 to $65 .{ }^{3}$ Likert scale: 1 to $7 .{ }^{4}$ Likert scale: 1 to $5 ;{ }^{* *} p<0.05 ;{ }^{* * *} p<0.01$ two-tailed.

Table 3 shows the variance analysis results and Schéffe's means comparison test for the three stages of economic development. As expected, the social entrepreneur's profile varies significantly according to the economic development of the entrepreneur's country. Entrepreneurs in developed countries are characterized by older age (41.52 years old) and a higher level of education than in developing and undeveloped countries. Social orientation also differs; developing countries have a greater social orientation than undeveloped (3.95) and developed (3.79) ones. The most outstanding differences took place, as expected, between undeveloped and developed countries. However, the expected relationships were generally satisfied.

Table 3. Variance analysis and means comparison.

\begin{tabular}{|c|c|c|c|c|c|c|c|}
\hline & \multirow{2}{*}{$\begin{array}{c}\text { Undeveloped } \\
\text { Countries } 1\end{array}$} & \multirow{2}{*}{$\begin{array}{l}\text { Developing } \\
\text { Countries } 2\end{array}$} & \multirow{2}{*}{$\begin{array}{l}\text { Developed } \\
\text { Countries } 3\end{array}$} & \multirow{2}{*}{$\mathbf{F}$} & \multicolumn{3}{|c|}{ Comparison of Means } \\
\hline & & & & & $1-2$ & $1-3$ & $2-3$ \\
\hline Age & 35.92 (11.66) & $38.81(13.23)$ & $41.52(12.85)$ & $1354^{* * *}$ & $* * *$ & $* * *$ & $* * *$ \\
\hline Education Level & $2.25(1.8)$ & $3.71(1.45)$ & $4.11(1.24)$ & $877,748 * * *$ & $* * *$ & $* * *$ & $* * *$ \\
\hline $\begin{array}{c}\text { Social } \\
\text { Orientation }\end{array}$ & $3.25(1.59)$ & $3.95(1.24)$ & $3.79(1.351)$ & $163,388^{* * *}$ & $* * *$ & $* * *$ & N.S \\
\hline Number of cases & 1563 & 3067 & 3261 & & & & \\
\hline
\end{tabular}

All the hypotheses were tested using hierarchical multiple regression (Table 4). To examine the effects of the hypothesized interactions, variables were entered using a two-step process [48]. Model I 
examines the relationship among gender, age, level of education, the economic development level of a country and social orientation. Model II gives further information by observing which of the entrepreneurial characteristics has the strongest relationship with social orientation in each type of economic development. The country's economic development is used as a dummy variable. There are two categories-undeveloped countries and developed countries-which have been analyzed directly, leaving developing countries as a reference category. The interaction terms were calculated as the product of these variables. The results of the regression analysis are shown in Table 4 .

Multicollinearity was tested in all the models and the variance inflation factor (VIF) values were between 1.00 and 3.2, which means that multicollinearity is not a significant problem. Moreover, with the estimation and analysis of the residuals it can be confirmed that the sample complies with the assumptions of linearity, homoscedasticity, independence and normality, following the recommended methodology [49].

The results of the regressions are shown in Table 4. In particular, the standardized coefficient and its statistical significance are included, as well as the R2 and the increase of R2 and the associated F with the model. As can be observed, all the models are significant. This means that the independent variables, as a whole, explain variations in the measures of the results. Although the R2 is low, it should be mentioned that this paper only analyzes the effect of some individual variables, but does not include the influence on social orientation of some other individual or external variables.

In Model I there is a partial positive association of gender, age and education level with social orientation. Furthermore, the education level has the strongest influence on social orientation $(\beta=0.125$, $p<0.01)$. The coefficient is positive and significant for developed countries $(\beta=0.070, p<0.01)$, whereas it is negative and significant for undeveloped countries $(\beta=-0.126, p<0.01)$. This indicates that social entrepreneurs in developed countries have a greater social orientation than in undeveloped countries.

Table 4. Hierarchical regression results.

\begin{tabular}{lcc}
\hline \multicolumn{1}{c}{ Variable } & Model I & Model II \\
\hline Gender & $0.032^{* * *}$ & $0.021^{* * * *}$ \\
Age & $0.044^{* * *}$ & $0.059^{* * *}$ \\
Education Level & $0.125^{* * *}$ & $0.079^{* * *}$ \\
Undeveloped Countries (DC) & $-0.126^{* * *}$ & $-0.099^{* * *}$ \\
Developed Countries (UC) & $0.070^{* * *}$ & $0.089^{* * *}$ \\
Gender-UC & & $-0.79^{* * *}$ \\
Gender-DC & & $0.26^{* * *}$ \\
Age-UC & & $0.013^{* * *}$ \\
Age-DC & & $-0.015^{* * *}$ \\
Educational Level-UC & & $0.055^{* * *}$ \\
Educational Level-DC & & $0.026^{* * *}$ \\
F-ratio & $56.419^{* * *}$ & $27.031^{* * *}$ \\
R-Square & $0.037^{* * *}$ & $0.039^{* * *}$ \\
$\boldsymbol{R}$-Square Adj. & $0.036^{* * *}$ & $0.037^{* * *}$ \\
$\boldsymbol{\Delta} \mathbf{R}^{2}$ & & $0.001^{* * *}$ \\
Std. Error of Estimate & $1.301^{* * *}$ & $1.301^{* * *}$ \\
* $_{* * *} p<0.01$ regression coefficients shown are beta coefficients. One-tailed.
\end{tabular}

In Model II, gender, age and education level again have a partial positive association with social orientation. These results confirm H2, H4 and H6. Therefore, it can be assessed that the entrepreneur's gender influences their social orientation. Social orientation is greater for women, the entrepreneur's age influences their social orientation. Social orientation becomes greater as they get older and the entrepreneur's education influences their social orientation. Social orientation becomes greater as they become more educated.

The coefficient for developed countries is again positive and significant in Model II, while it is also negative and significant for undeveloped countries. This indicates that H1, which states 
that, "The country's economic development influences the entrepreneur's social orientation. Social orientation is greater as economic development increases," is also confirmed.

To test if the different levels of economic development have an influence on the direction or the strength of the relationship between the independent variables and the entrepreneur's social orientation, we propose hypothesis H3, H5 and H7. According to Baron and Kenny [50], there are three main conditions, which are required to support a moderation effect:

(1) The interaction should be significant (gender-underdeveloped countries (UC); gender-developed countries (DC); age-UC; age-DC; educational level-UC; educational level-DC).

(2) It is desirable for the moderator variable (UC, DC) to be uncorrelated with both the independent (gender, age, education level) and the dependent variable (Social Orientation).

(3) The moderator variable (UC, DC) must function as an independent variable.

In this study, the last two conditions are satisfied (Table 2; Table 4), and as shown in Table 4, first, the interactions between the level of education and the moderator variables are positive and significant for the two country categories. That result allows us to accept H7, so we can affirm that "the country's economic development moderates the influence of education on social orientation". More specifically, data confirm H7.1 (in developed countries the most educated have more social orientation) and also H7.2 (in the less developed, less educated entrepreneurs have more social orientation than the most educated). For gender (H3), the interaction is significant only for developed countries, so it can be said that "the country's economic development moderates the influence of gender on social orientation" for this category of economic development, so we can accept H3.1 and reject H3.2. On the other hand, H5 (H5.1 and H5.2) must be rejected since age has not obtained significant results.

There has been an increase in social entrepreneurship literature in the last few decades. Nevertheless, only a few studies have focused on why the social orientation of social enterprises differs from one enterprise to another.

\section{Conclusions}

This article complements previous social entrepreneurial research that has debated which variables are significantly correlated with a social entrepreneur's social orientation. Although it is generally assumed that social entrepreneurs seek social value, research shows that the objective of social entrepreneurs can include a wide range of value creation targets, including economic value [51].

Entrepreneurship benefits society because it solves problems, recognizes opportunities, and designs new products and services or raises the efficiency of existing ones [13,52]. Moreover, social entrepreneurship has been recognized as a tool to solve society's becoming change agents who employ entrepreneurial means to provide systemic solutions to social and environmental problems [24].

The present paper consolidates the developments in the extant literature on the contribution of social entrepreneurship and may help governments to improve development-effective decision-making, depending on the particular context. Previous research in this area has largely been based on case studies, and later, on large surveys in specific countries. These research methods enhance the academic knowledge of a phenomenon but do not enable the creation of generic, causal inferences. This paper closes this gap, with an empirical study with a large sample, enabling us to generalize the data obtained. In particular, our results corroborate the arguments found in the related psychology literature. Biological variables, such as an individual's gender and age, influence a person's social orientation. Education level also conditions an individual with regards to becoming socially oriented. In addition, external variables also condition people's social orientation, as in the case of the economic development level of the country in which the individual lives.

This study shows that development level influences social entrepreneurs' social orientation through the observation that, as a country's development level increases, so does the likelihood of an individual having a social orientation. The data confirm that rates of social orientation among 
entrepreneurs are lower in less developed countries, where the population needs to create more economic value for the population's support and survival. In contrast, people can be more oriented toward the creation of social value in more developed countries, where most primary services are ensured for the population.

Regarding gender, our findings support the literature by replicating the roles that a patriarchal society attributes to both genders; women were observed to be more affected by social and environmental benefits, which can be attributed to their more common roles of caretaker of the home, children, and other adults, whereas men were identified with economic objectives to a greater extent by being assigned, for example, the function of economic supporter of the household. Therefore, the results of this paper confirm that men give more importance to money and their career, showing a more prominent ethics of justice. On the other hand, women give more importance to providing socially by maintaining relationships, helping others and helping nature [22].

However, significant results were only obtained in developed countries, and the development level moderated the influence of gender on an individual's social orientation. The results obtained suggest that in undeveloped countries, there are probably greater needs for women. In these types of countries, men tend to work, while women are limited to taking care of the home and dependents. For this reason, it is more difficult for women to find a job; that is, women face more challenges to support themselves economically and survive independently.

As for the relationship between a social entrepreneur's age and the creation of social value, older individuals are more socially oriented, perhaps being more mature and aware of the problems in the world [43]. Older people are likely to have earned and saved money throughout their lives and can decide to focus on creating benefits for society, since they tend to have more money saved and lower family burdens than younger individuals [53]. Development level does not moderate the relationship between this variable and the individual's social orientation.

Finally, we confirmed that the education level has a positive relationship with the generation of social value. These results are supported by the fact that people with a higher level of education are more able to find skilled, enriching and motivating jobs, which in turn involve higher salaries. Therefore, for these people, starting a business may be primarily conditioned not by economic benefit but by the creation of social value for others, which could also lead to self-fulfillment through their jobs [54]. The relationship between this variable and an individual's social orientation is moderated by the country's development level, with the observation of a greater social orientation among the most qualified people in developed countries. Similarly, to those with a higher level of education, inhabitants of developed countries, unlike the inhabitants of less developed countries, are more likely find skilled, enriched and motivating jobs, with higher salaries. Furthermore, a greater development of institutions and the welfare state leads to a better socioeconomic situation for the individuals in developed countries. This encourages these individuals to have a greater social orientation than those in less developed countries, where a worse socioeconomic situation means that individuals cannot typically afford to be only socially oriented, but must also be economically oriented so that they and their families can survive [55].

Therefore, the results of this paper show that older women with a high level of education have the greatest social orientation among social entrepreneurs. In addition, we found that an individual's social orientation increases as their country's development level increases. However, the level of development only moderates the relationship between the social orientation, gender and education of the individual.

Those findings have practical and policy implications to support social entrepreneurship. The likelihood that social enterprises will survive depends on entrepreneurs having previous relevant entrepreneurship experience in the sector, so efforts in policy making can help future social entrepreneurs to develop these skills through education, training, networks and incubators, and growth accelerators. Since the level of development moderates an individual's orientation, countries should develop a legal status dealing with social entrepreneurship that recognizes the duality of social and economic 
objectives [23]. This status could produce an increase in the number of social enterprises in any territory, although possibly more so in less developed countries, where an individual's social orientation tends to be lower. For this reason, regulating companies with dual social and economic objectives may lead individuals to create more social enterprises, which will create much needed social benefits.

Some limitations were identified throughout the development of this paper. The design of this study was cross-sectional, which does not enable examination of the causal relationships among the variables through time. The examined factors condition the social orientation of social entrepreneurs currently and will probably do so in the future, but time could also cause some of these variables to decrease in importance, or allow variables to appear.

Our findings lead us to suggest several areas for continued research. Future research could study the age variable further, since we could not affirm that the level of development moderates its relationship with social orientation. In addition, the way an individual's socioeconomic situation and purchasing power, or that of their relatives or friends, influences social orientation could be examined. We analyzed the influence of those four variables as antecedents, but in subsequent studies, it will be important to analyze other variables that may help us to understand more completely the profile of the social entrepreneur, such as religious affiliation, experience and even one's social network. It would also be appropriate to set up new studies with qualitative methodologies to validate our results, that explain why an entrepreneur's social orientation depends on gender, age, education and economic development (measured as a categorical or continuous variables).

Finally, this analysis was a contribution to the scarce literature on the social orientation of social entrepreneurs, using an empirical study that enables the generalization of the results achieved. This research is expected to increase knowledge in the scientific field on the creation of social enterprises, encouraging further research on an individual's social orientation and on the issues that condition entrepreneurs. This research should also enhance knowledge in the business world, where the creation of these enterprises can be considered job opportunities for any person, and would directly generate much needed benefits for others.

Author Contributions: The contributions to this paper were made equally.

Funding: No external funding was received for this research.

Conflicts of Interest: No conflict of interest is declared by the authors.

\section{References}

1. Bosma, N.; Schott, T.; Terjersen, S.; Kew, P. Special Topic Report Social Entrepreneurship; Global Entrepreneurship Research Association: London, UK, 2016. Available online: https://www.researchgate.net/publication/ 303686607_Global_Entrepreneurship_Monitor_2015_to_2016_Special_Report_on_Social_Entrepreneurship (accessed on 20 August 2019).

2. Santos, F.M. A Positive Theory of Social Entrepreneurship. J. Bus. Ethics 2012, 111, 335-351. [CrossRef]

3. Child, C.; Witesman, E.M.; Braudt, D.B. Sector choice: How fair trade entrepreneurs choose between nonprofit and for-profit forms. SAGE J. 2015, 44, 832-851. [CrossRef]

4. Heinze, K.L.; Banaszak-Holl, J.; Babiak, K. Social Entrepreneurship in Communities. Nonprofit Manag. Leadersh. 2016, 26, 313-330. [CrossRef]

5. Murphy, P.J.; Coombes, S.M. A Model of social entrepreneurial Discovery. J. Bus. Ethics 2009, 87, 325-336. [CrossRef]

6. Nga, J.K.H.; Shamuganathan, G. The Influence of Personality Traits and Demographic Factors on Social Entrepreneurship Start Up Intentions. J. Bus. Ethics 2010, 95, 259-282.

7. Christopoulos, D.; Vogl, S. The motivation of social entrepreneurs: The roles, agendas and relations of altruistic economic actors. J. Soc. Enterp. 2015, 6, 1-30. [CrossRef]

8. Ge, J.; Xu, H.; Pellegrini, M.M. The Effect of Value Co-Creation on Social Enterprise Growth: Moderating Mechanism of Environment Dynamics. Sustainability 2019, 11, 250. [CrossRef]

9. Renko, M. Early challenges of nascent social entrepreneurs. Entrep. Theory Pract. 2013, 37, 1045-1069. [CrossRef] 
10. Addae, A.E. Pathways to sector selection: A conceptual framework for social enterprises. Nonprofit Manag. Leadersh. 2018, 28, 349-365. [CrossRef]

11. Lepoutre, J.; Justo, R.; Terjesen, S.; Bosma, N. Designing a global standardized methodology for measuring social entrepreneurship activity: The Global Entrepreneurship Monitor social entrepreneurship study. Small Bus. Econ. 2013, 40, 693-714. [CrossRef]

12. Grieco, C. What do social entrepreneurs need to walk their talk? Understanding the attitude-behavior gap in social impact assessment practice. Nonprofit Manag. Leadersh. 2018, 29, 105-122. [CrossRef]

13. Pejic Bach, M.; Aleksic, A.; Merkac-Skok, M. Examining determinants of entrepreneurial intentions in Slovenia: Applying the theory of planned behaviour and an innovative cognitive style. Econ. Res. Ekon. Istraz. 2018, 31, 1453-1471.

14. Nicolás, C.; Rubio, A. Social enterprise: Gender gap and economic development. Eur. J. Manag. Bus. Econ. 2016, 25, 56-62. [CrossRef]

15. Germak, A.J.; Robinson, J.A. Exploring the motivation of nascent social entrepreneurs. J. Soc. Enterp. 2014, 5, 5-21. [CrossRef]

16. Sastre-Castillo, M.A.; Peris-Ortiz, M.; Valle, I.D.-D.; Sastre-Castillo, M.A.; Peris-Ortiz, M. What Is Different about the Profile of the Social Entrepreneur? Nonprofit Manag. Leadersh. 2015, 25, 349-369. [CrossRef]

17. Hechavarría, D.M.; Ingram, A.; Justo, R.; Terjesen, S. Are women more likely to pursue social and environmental entrepreneurship. In Global Women's Entrepreneurship Research: Diverse Settings, Questions and Approaches; Hughes, K.D., Jennings, J.E., Eds.; Edward Elgar Publishing: Cheltenham, UK, 2012; pp. 135-151.

18. Nicolás, C.; Rubio, A.; Fernandez-Laviada, A. Cognitive Determinants of Social Entrepreneurship: Variations According to the Degree of Economic Development. J. Soc. Enterp. 2018, 9, 154-168. [CrossRef]

19. Langowitz, N.; Minniti, M. The Entrepreneurial Propensity of Women. Enterp. Theory Pract. 2007, 31, 341-364. [CrossRef]

20. Putnam, R.P. Bowling Alone: The Collapse and Revival of American Community; Simon and Schuster: New York, NY, USA, 2000.

21. Levie, J. From Business Plans to Business Shaping: Reflections on an Experiential New Venture Creation Class; National Council for Graduate Entrepreneurship: Coventry, UK, 2006.

22. Hechavarría, D.M. The impact of culture on national prevalence rates of social and commercial entrepreneurship. Int. Enterp. Manag. J. 2016, 12, 1025-1052. [CrossRef]

23. Terjesen, S.; Bosma, N.; Stam, E. Advancing public policy for high-growth, female, and social entrepreneurs. Public Adm. Rev. 2016, 76, 230-239. [CrossRef]

24. Bansal, S.; Garg, I.; Deep Sharma, G. Social Entrepreneurship as a Path for Social Change and Driver of Sustainable Development: A Systematic Review and Research Agenda. Sustainability 2019, 11, 1091. [CrossRef]

25. Moskovskaya, A.A.; Soboleva, I.V. Social entrepreneurship in the system of social policy: International experience and prospects of Russia. Stud. Russ. Econ. Dev. 2016, 27, 683-688. [CrossRef]

26. Yunis, M.S.; Hashim, H.; Anderson, A.R. Enablers and Constraints of Female Entrepreneurship in Khyber Pukhtunkhawa, Pakistan: Institutional and Feminist Perspectives. Sustainability 2019, 11, 27. [CrossRef]

27. Bahena-Álvarez, I.L.; Cordón-Pozo, E.; Delgado-Cruz, A. Social Entrepreneurship in the Conduct of Responsible Innovation: Analysis Cluster in Mexican SMEs. Sustainability 2019, 11, 3714. [CrossRef]

28. McCarthy, D.J.; Puffer, S.M.; Lamin, A. Entrepreneurial orientation in a hostile and turbulent environment: Risk and innovativeness among successful Russian entrepreneurs. Eur. J. Int. Manag. 2018, 12, 191. [CrossRef]

29. Rey-Martí, A.; Mohedano-Suanes, A.; Simón-Moya, V. Crowdfunding and Social Entrepreneurship: Spotlight on Intermediaries. Sustainability 2019, 11, 1175. [CrossRef]

30. Murphy, R.O.; Ackermann, K.A. Social value orientation: Theoretical and measurement issues in the study of social preferences. Personal. Soc. Psychol. Rev. 2014, 18, 13-41. [CrossRef] [PubMed]

31. Höflinger, P.J.; Nagel, C.; Sandner, P. Reputation for technological innovation: Does it actually cohere with innovative activity? J. Innov. Knowl. 2018, 3, 26-39. [CrossRef]

32. Rajapathirana, R.J.; Hui, Y. Relationship between innovation capability, innovation type, and firm performance. J. Innov. Knowl. 2018, 3, 44-55. [CrossRef]

33. Moisescu, O.-I. From perceptual corporate sustainability to customer loyalty: A multi-sectorial investigation in a developing country. Econ. Res. Ekon. Istraz. 2018, 31, 55-72. [CrossRef] 
34. Coduras, A.; Autio, E. Comparing subjective and objective indicators to describe the national entrepreneurial context: The Global Entrepreneurship Monitor and the Global Competitiveness Index contributions. Investig. Reg. 2013, 26, 47-74.

35. Hunter, L.M.; Hatch, A.; Johnson, A. Cross-National Gender Variation in Environmental Behaviors. Soc. Sci. Q. 2004, 85, 677-694. [CrossRef]

36. Eagly, A. Sex Differences in Social Behavior: A Social-Role Interpretation; Erlbaum: Hillsdale, MI, USA, 1987.

37. Connell, R.W. An iron man: The body and some contradictions of hegemonic masculinity. In Sport, Men and the Gender Order; Messner, M., Sabo, D., Eds.; Human Kinetics Books: Champaign, IL, USA, 1990; pp. 141-149.

38. Bandura, A. La Auto-Eficacia: El Ejercicio Del Control; W. H. Feeman: New York, NY, USA, 1994.

39. Luchsinger, G. UN Woman 2014-2015 Annual Report; UN: New York, NY, USA, 2015. Available online: http://www2.unwomen.org/-/media/annual\%20report/attachments/sections/library/un-women-annualreport-2014-2015-en.pdf?vs=522 (accessed on 20 August 2019).

40. Neupert, K.E.; Baughn, C.C. Immigration, education and entrepreneurship in developed countries. J. Enterp. Communities People Places Glob. Econ. 2013, 7, 293-310. [CrossRef]

41. Lévesque, M.; Minniti, M. The effect of aging on entrepreneurial behavior. J. Bus. Ventur. 2006, 21, $177-194$. [CrossRef]

42. Corner, P.D.; Ho, M. How Opportunities Develop in Social Entrepreneurship. Enterp. Theory Pract. 2010, 34, 635-659. [CrossRef]

43. Johnson, S. Social Entrepreneurship Literature Review. New Acad. Rev. 2003, 2, 42-56.

44. Maslow, A.H. Motivación y Personalidad; Sagitario: Barcelona, Spain, 1963.

45. Hambrick, D.C.; Mason, P.A. Upper Echelons: The Organization as a Reflection of Its Top Managers. Acad. Manag. Rev. 1984, 9, 193-206. [CrossRef]

46. Di Domenico, M.; Haugh, H.; Tracey, P. Social Bricolage: Theorizing Social Value Creation in Social Enterprises. Enterp. Theory Pract. 2010, 34, 681-703. [CrossRef]

47. Alonso, J.A. Emigración, Pobreza y Desarrollo; Catarata: Madrid, Spain, 2004.

48. Cohen, J.; Cohen, P.; West, S.G.; Aiken, L.S. Applied Multiple Regression for the Behavioral Sciences; Laurence Erlbaum: Hillsdale, MI, USA, 1983.

49. Hair, J.F.; Anderson, R.E.; Tatham, R.L.; Black, W.C. Análisis Multivariante; Prentice Hall: Madrid, Spain, 1999.

50. Baron, R.M.; Kenny, D.A. The moderator-mediator variable distinction in social psychological research: Conceptual, strategic, and statistical considerations. J. Personal. Soc. Psychol. 1986, 51, 1173-1182. [CrossRef] [PubMed]

51. Boluk, K.A.; Mottiar, Z. Motivations of social entrepreneurs: Blurring the social contribution and profits dichotomy. Soc. Enterp. J. 2014, 10, 53-68. [CrossRef]

52. Khan, K.U.; Xuehe, Z.; Atlas, F.; Khan, F. The impact of dominant logic and competitive intensity on SMEs performance: A case from China. J. Innov. Knowl. 2019, 4, 1-11. [CrossRef]

53. Piotrowski, S.J.; Van Ryzin, G.G. Citizen Attitudes toward Transparency in Local Government. Am. Rev. Public Adm. 2007, 37, 306-323. [CrossRef]

54. Arenius, P.; Minniti, M. Perceptual Variables and Nascent Entrepreneurship. Small Bus. Econ. 2005, 24, 233-247. [CrossRef]

55. Zahra, S.A.; Gedajlovic, E.; Neubaum, D.O.; Shulman, J.M. A typology of social entrepreneurs: Motives, search processes and ethical challenges. J. Bus. Ventur. 2009, 24, 519-532. [CrossRef]

(C) 2019 by the authors. Licensee MDPI, Basel, Switzerland. This article is an open access article distributed under the terms and conditions of the Creative Commons Attribution (CC BY) license (http://creativecommons.org/licenses/by/4.0/). 